\title{
Meta-Analysis of the Effect of Policy Lockdown on Anxiety in Adults
}

\author{
Isna Nur Rohmah'), Fauzia Ichlasul Sekar²), Galang Aji Samudera²), Hakim Anasulfalah5), \\ Hepti Widia Ningsih7), Izdihar Azzah Paramastri5), Masromi Hendria Wijayanto4), Meike \\ Arianty6), Muhammad Dudayev Caesar Putra3), Muhammad Fajar Husein5) \\ ${ }^{1)}$ Health Polytechnic, Ministry of Health, Semarang, Central Java \\ ${ }^{2}$ Health Polytechnic, Ministry of Health, Surakarta, Central Java \\ 3) Jember Health Polytechnic, East Java \\ 4) Jenderal Soedirman University, Banyumas, Central Java \\ 5)Muhammadiyah Surakarta University, Central Java \\ 6)Academy of Midwifery Anugerah Bintan Tanjungpinang, Kepulauan Riau, Indonesia \\ 7)Aisyiyah' Yogyakarta University, Yogyakarta, Indonesia
}

\section{ABSTRACT}

Background: On March 11, 2020, the World Health Organization (WHO) has declared an outbreak of a new coronavirus (COVID-19) as a global pandemic. In responding to the threat of the COVID-19 virus pandemic, policymakers have implemented a policy lockdown that can cause psychological distress, one of which is anxiety. This study aims to examine the effect of the policy lockdown on anxiety in adults using a meta-analysis.

Subjects and Method: Meta-analysis was performed by searching for articles from the database, namely PubMed, Google Scholar, Science Direct, Scopus, and Crossref. The keywords used are "Anxiety" AND "Adult" AND "COVID-19" OR "SARS-CoV-2" AND "Lockdown" OR "Movement Restriction" OR "quarantine" OR "shutdown". The inclusion criteria in this study were full-text articles with a crosssectional design, in English, published in the period 2019-2021. Analysis of the article using RevMan 5.3.
Results: Four articles were analyzed. The results of the meta-analysis showed that anxiety in adults with the implementation of the policy lockdown was 1.94 times more at risk than those who did not implement the policy lockdown, but it was not significant in increasing anxiety in adults $(\mathrm{aOR}=1.94 ; 95 \% \mathrm{CI}=$ 0.79 to $4.74 ; p=0.150)$.

Conclusion: Anxiety in adults with the implementation of the policy is lockdown more at risk than those who have not implemented the policy lockdown, but it is not significant in increasing anxiety in adults.

Keywords: Anxiety, lockdown, covid-19

\section{Correspondence:}

Isna Nur Rohmah. Health Polytechnic, Ministry of Health, Semarang. Jl. Tirto Agung, Pedalangan, Banyumanik, Semarang City, Central Java 50268. Email: isnanr28@gmail.com. Mobile: +6281327215685

Cite this as:

Rohmah IN, Sekar FI, Samudera GA, Anasulfalah H, Ningsih HW, Paramastri IA, Wijayanto MH, Arianty M, Putra MDC, Husein MF (2021). Meta-Analysis of the Effect of Policy Lockdown on Anxiety in Adults. J Health Policy Manage. 06(02): 139-147. https://doi.org/10.26911/thejhpm.2021.06.02.06.

c) (-) Journal of Health Policy and Management is licensed under a Creative Commons Attribution-Non Commercial-Share Alike 4.o International License.

\section{BACKGROUND}

On March 11, 2020, the World Health Organization (WHO) declared the new coronavirus outbreak (COVID-19) a global pandemic (WHO, 2020b in Prati 2020). The COVID-19 coronavirus (SARS-CoV-2) pan- demic is currently causing considerable psychological and physical distress as well as high morbidity and mortality rates worldwide since its outbreak in December 2019 (Wang et al., 2020) 
Some of the negative effects of COVID -19 have been noted on the psychological wellbeing of individuals undergoing lockdown in various parts of the world. Anxiety and depression have been the most studied problems, although stress and PTSD symptoms as well as fatigue and sleep disturbances have also been reported. Most of these studies have focused on the prevalence of this problem. For example, in a sample from China, 35\% had anxiety, 20\% depression, and 8\% sleep disorders. Similar rates were reported in another sample from China for anxiety at $29 \%$, depression at $17 \%$, and stress at $8 \%$. And, in a sample from Italy, similar prevalence data were recorded including 33\% for anxiety and 24\% for depression (Field et al., 2020).

A survey on mental health in Indonesia through self-examination conducted by the Association of Indonesian Mental Medicine Specialists (PDSKJI) conducted online found that as many as 63 percent of respondents experienced anxiety and 66 percent of respondents experienced depression due to the COVID-19 pandemic. The highest age group experiencing the disorder is 17-29 years old. The main symptoms of anxiety are feeling worried that something bad will happen, excessive worry, irritability, and difficulty relaxing. While the main symptoms of depression that appear are sleep disturbances, lack of confidence, fatigue, lack of energy, and loss of interest. Furthermore, as many as 80 percent of respondents had symptoms of post-traumatic psychological stress due to experiencing or witnessing unpleasant events related to COVID-19. 46 percent of respondents experienced severe post-traumatic stress symptoms, 33 percent of respondents experienced moderate post-psychological stress symptoms, 2 percent of respondents experienced mild post-traumatic stress symptoms, while 19 percent had no symptoms.
The post-traumatic stress symptom that stands out is feeling distant and separated from other people and feeling constantly alert, careful, and on guard.

The Coronavirus pandemic affects the health of the people, both physical and mental health. According to Thakur and Jain (2020), there are at least four main risk factors for mental health disorders that are commonly encountered, which arise due to the COVID-19 pandemic, namely isolation, and social distancing, economic pressure, stress, and depression in health workers and stigma and discrimination.

First, isolation and social distancing cause a lot of public anxiety. However, in this case, the vulnerability occurs in people who are at risk of depression and individuals who live in solitude. Feelings of alienation from social distancing and independent isolation have disrupted normal activities. Such people are self-judging, have extreme suicidal thoughts. The enforced isolation and quarantine interferes with normal social life and creates psychological fear and feelings of trapping, for an indefinite period of time (Thakur and Jain, 2020).

Second, a worldwide lockdown creates an economic recession. The shadow of an economic crisis can cause panic, mass unemployment, poverty, and homelessness. This may increase the risk of suicide or lead to an increase in community suicide attempts. Third, Stress, anxiety, and stress on medical health care professionals. Medical professionals are in close contact with COVID-19 positive patients and/or are quarantined while treating them under psychological trauma. The predictors are a constant fear of getting infected, unbearable stress, helplessness, and the distress of watching an infected patient die alone. Fourth, the social boycott and discrimination also added several cases to the list of 
suicides due to COVID-19 (Thakur and Jain, 2020).

The study aims to explore the psychological effects of a lockdown such as anxiety. It is hoped that this research will adequately inform public health care systems and enable adequate action to protect against or reduce adverse mental health effects.

\section{SUBJECTS AND METHOD}

\section{Study Design}

This was a meta-analysis study. This study uses data from the results of previous studies where the researcher presents a summary in accordance with the questions formulated by the researcher. Cross-sectional design with multivariate analysis showing the results of the Adjusted Odds Ratio (aOR), and articles published in 2019-2021. The articles used in the meta-analysis are available in the electronic databases at Pubmed, Google Scholar, Scopus, Sciencedirect, Crossref. The keywords used are "Anxiety" AND "Adult" AND "COVID-19" OR "SARS-CoV-2" AND "Lockdown" OR "Movement Restriction" OR "quarantine" OR "shutdown". Articles were searched by considering the eligibility criteria determined using the PICO model. The study population was adults. The intervention was areas with the implementation of policies lockdown. The comparison was areas with no implementation of policies lockdown. The outcome was adults with anxiety.

\section{Inclusion Criteria}

The articles included in this study were fulltext articles with a cross-sectional study design with multivariate analysis, areas with the implementation of policies lockdown interventions and adults with anxiety was the outcome and the articles used in this study were published in English.

\section{Exclusion Criteria}

Exclusion criteria were taken the articles published in this study were articles with a random controlled trial, case-control, and quasi-experiment. The articles were not published in English. The statistical results reported were not aOR. Criteria in this study were duplicate articles and articles that had been meta-analysis.

\section{Study Variables}

This was meta-analysis research with the theme of the effect of the lockdown policy on anxiety in adults. The independent variable in this study is anxiety in adults, while the dependent variable in this study is the lockdown policy in the era of the COVID-19 pandemic. The study design used in the article included in the inclusion criteria was an observational and cross-sectional study design.

\section{Operational Definition of Variables} Lockdown is an action or emergency condition when people stop temporarily or leave a designated area or building during a hazard.

Anxiety is the feeling or emotion of fear, fear, and impending but not as crippling disaster as anxiety disorders. The research instrument used was a questionnaire, with a categorical data scale.

\section{Study Instruments}

The Stages of this research follow the PRISMA Flow diagram and the assessment of the quality of research articles using the Critical Appraisal Skills Program CASP) for cross-sectional.

\section{Data Analysis}

Data analysis in this study used RevMan 5.3 and the results of the analysis were included in this study using the Random Effect model.

\section{RESULTS}

The process of searching for articles by searching through an article database 
Rohmah et al./ Meta-Analysis of the Effect of Policy Lockdown on Anxiety in Adults

which includes: PubMed, Springer Link, Science Direct, and Google Scholar. The keywords include: "Anxiety "AND Adult AND" COVID-19 "OR" SARS-CoV-2 "AND" Lockdown "OR" Movement Restriction "OR" quarantine "OR" shutdown. Here are the search results to articles Main Metaanalysis.

The initial search process yielded 1245 articles, after the removal process of published articles found 1119 articles, 88 of which met the requirements for the next full-text review. The results of the articles that met the qualitative requirements were reviewed and four articles were reviewed. Qualified of the four articles following the model PICO and the predetermined criteria, the research was conducted from several countries. Some countries, namely Bangladesh, China, and Italy. Overview of primary studies can be seen in table 1 .

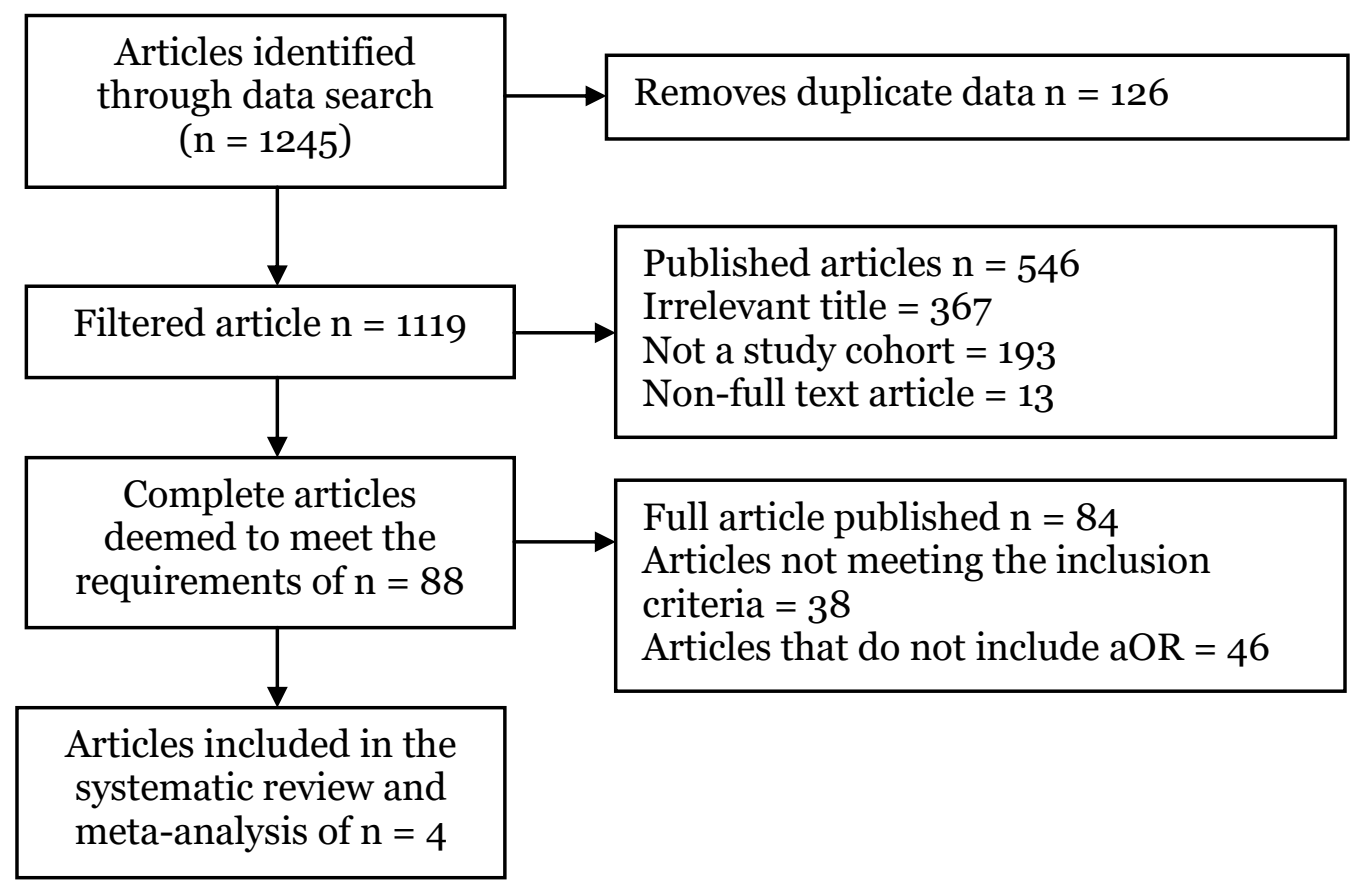

Figure 1. Prisma Flowchart

Table 1. Summary of Sources policy Influence Lockdown to Anxiety

\begin{tabular}{|c|c|c|c|c|c|c|}
\hline Author & Country & $\begin{array}{l}\text { Sample } \\
\text { size, age }\end{array}$ & Population & $\begin{array}{l}\text { Intervention (I), } \\
\text { Comparison (C) }\end{array}$ & $\begin{array}{c}\text { Results } \\
\text { (Outcome) }\end{array}$ & $\begin{array}{l}\text { aOR Effect } \\
\text { (95\% CI) }\end{array}$ \\
\hline $\begin{array}{l}\text { Khan et } \\
\text { al., 2020 }\end{array}$ & Bangladesh & $\begin{array}{l}505, \quad 19-25 \\
\text { years old }\end{array}$ & $\begin{array}{l}\text { University and } \\
\text { college students }\end{array}$ & $\begin{array}{l}\text { I: Lockdown } \\
\text { C: No Lockdown }\end{array}$ & Anxiety & $\begin{array}{l}3.95 \\
(1.95-5.96)\end{array}$ \\
\hline $\begin{array}{l}\text { Gan et al., } \\
2020\end{array}$ & China & $\begin{array}{l}\text { 1390, Mean } \\
29.09 \text { - } \\
31.38 \text { years }\end{array}$ & $\begin{array}{l}\text { Chinese } \\
\text { Population }\end{array}$ & $\begin{array}{l}\text { I: Lockdown } \\
\text { C: No Lockdown }\end{array}$ & Anxiety & $\begin{array}{l}0.12 \\
(0.02-0.22)\end{array}$ \\
\hline $\begin{array}{l}\text { Zhu et al., } \\
2020\end{array}$ & China & $\begin{array}{l}2269,30-51 \\
\text { years }\end{array}$ & $\begin{array}{l}\text { Chinese } \\
\text { Population }\end{array}$ & $\begin{array}{l}\text { I: Lockdown } \\
\text { C: No Lockdown }\end{array}$ & Anxiety & $\begin{array}{l}4,686 \\
(3,937- \\
5,579)\end{array}$ \\
\hline $\begin{array}{l}\text { Rossi et } \\
\text { al., } 2020\end{array}$ & Italy & $\begin{array}{l}\text { 18,147, } \\
\text { Median } 38 \\
\text { years }\end{array}$ & Population Italy & $\begin{array}{l}\text { I: Lockdown } \\
\text { C: No Lockdown }\end{array}$ & Anxiety & $\begin{array}{l}1.52 \\
(1.05-2.22)\end{array}$ \\
\hline
\end{tabular}


Rohmah et al./ Meta-Analysis of the Effect of Policy Lockdown on Anxiety in Adults

Odds Ratio

Odds Ratio

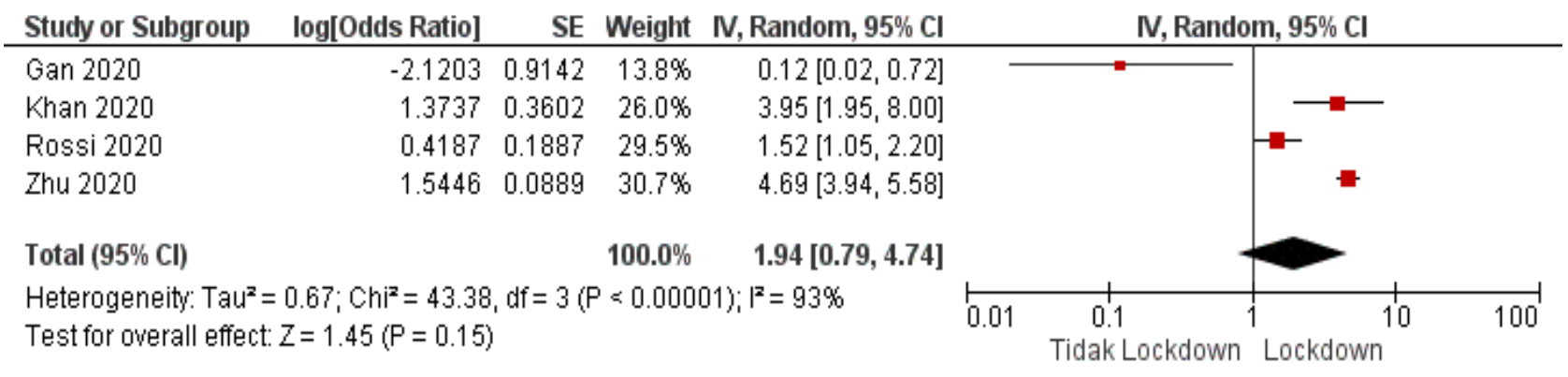

\section{Figure 2. Forest plot}

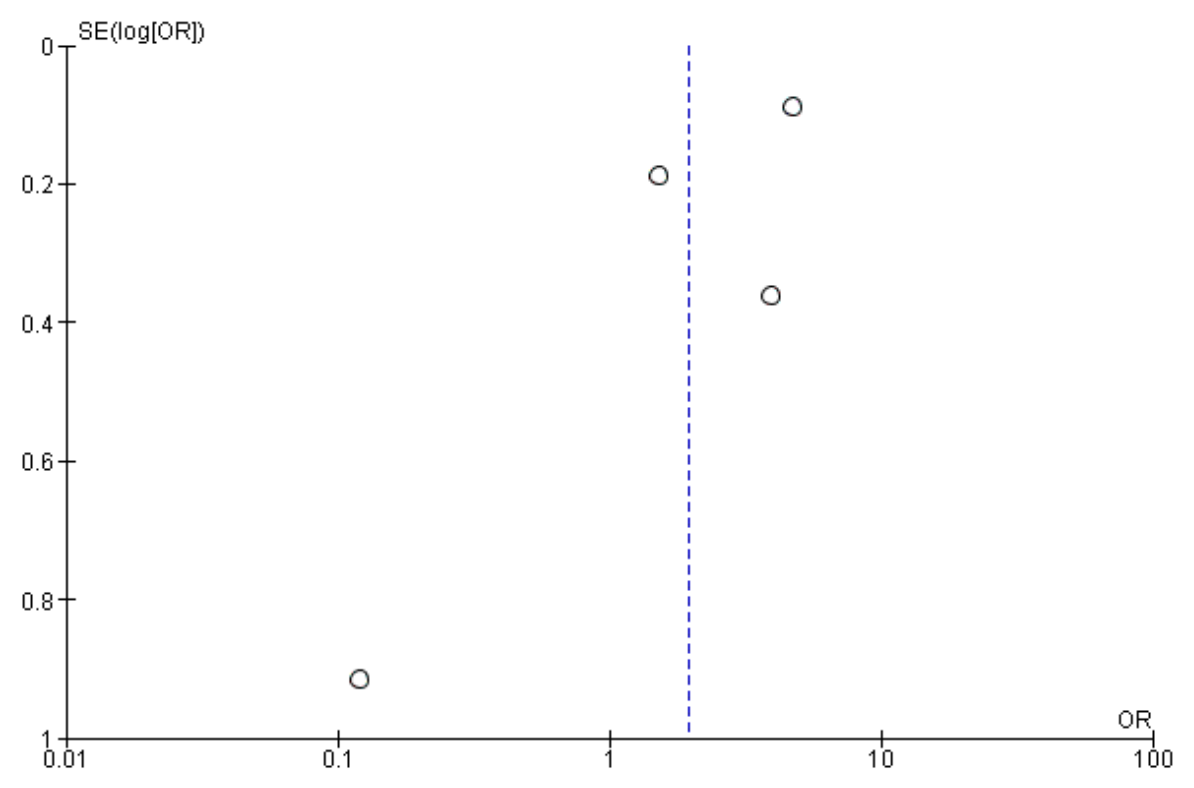

Figure 3. Funnel plot Policy Lockdown and Anxiety

Based on Figure 2 the results of the analysis show that the policy lockdown is a risk factor for worry. The results obtained showed a high heterogeneity between trials ( $\mathrm{p}<0.050 ; \mathrm{I}^{2}=93 \%$ ) so a model was used random-effect (REM). Lockdown could increase 1.94 times the risk of experiencing anxiety, but not significantly in increasing anxiety in adults $(\mathrm{aOR}=1.94 ; 95 \% \mathrm{CI}=0.79$ to $4.74 ; \mathrm{p}=0.150$ ).

Based on Figure 3 Funnel plot Policy, Lockdown against Anxiety the plot on the right and left sides are not symmetrical to each other and form a funnel upside down. The left plot has a standard error of $>0.8$ while in the right plot the standard error is
$<0.4$. This indicates that there is a bias in the research.

\section{DISCUSSION}

This was meta-analysis with the theme related to the effect of the policy lockdown on anxiety in adults. The independent variable in this study is anxiety in adults, while the dependent variable in this study is the policy lockdown in the era of the COVID-19 pandemic. The study design used in the article that fell into the inclusion criteria was an observational and cross-sectional study design. The study instrument used was a questionnaire using a measurement scale such as the Depression 
Anxiety Stress Scales 21 (DASS-21), the Public Health Emergency Scale, and the Generalized Anxiety Disorder Scale (GAD7). Depression Anxiety Stress Scales 21 (Lovibond and Lovibond, 1995) was used to assess the prevalence of stress, anxiety, and depression among students. This scale was also validated in Bangla (Alim et al., 2017). The scale contains 21 items divided equally by seven items into three subscales of stress, anxiety and depression.

The estimated effect of the policy lockdown on adult anxiety was processed using the RevMan 5.3 application with the method generic inverse variance. This method is used to analyze data in the form of rate, time-to-event, hazard ratio, ordinal scale, adjusted estimation, average differrence, or average ratio.

The study results from this metaanalysis are presented in the form of a forest plot and a funnel plot. The forest plot aims to provide an overview of the information from each of the studies examined in this meta-analysis and estimate the overall results (Murti, 2018). A funnel plot is a diagram in a meta-analysis used to show possible publication bias. The funnel plot shows the relationship between the study effect size and the sample size or effect size standard error of the various studies studied (Murti, 2018). The funnel plot shows visually the amount of variation (heterogeneity) (Akobeng, 2005 in Murti, 2018). The funnel plot shows the relationship between the study effect size and the sample size of the various studies studied, which can be measured in several different ways (Murti, 2018).

Based on the search for articles, four articles consisting of observational studies and cross-sectional studies as a source of meta-analysis of the effect of policies lockdown on anxiety in adults. Anxiety is a feeling of fear of something happening due to the anticipation of danger and is a signal that helps individuals to prepare to take action against threats. The influence of demands, competition, and disasters that occur in life can have an impact on physical and psychological health. One of the psychological impacts is anxiety or anxiety (Sutejo, 2018). Anjum et al. (2019) reported that $28.50 \%$ of students reported levels of mild to very severe stress $33.28 \%$ of students reported levels of mild to very severe anxiety, 46.92\% of students reported levels of mild to very severe depression caused by the outbreak. These findings are consistent with research conducted in China which has a higher level of psychological impact compared to the stress, anxiety, and depression in the general population in the early stages of the epidemic (Wang et al., 2020).

The educational activity is hindered because this closure can be a cause of higher stress in students which can be resolved with the necessary arrangements for online classes. Uncertainty about academic development can be a stressor for the minds of young people (Roy and Tripathy, 2020). In addition, according to Handayani et al. (2020) anxiety can also be triggered by several factors, including sociodemographic, stigma, and fear of exposure to Covid19 infection. The policies that have emerged due to the coronavirus outbreak can be seen with the closure of several road accesses at a certain time, restrictions on the number of transportations, restrictions on transportation operating hours, which of course the policy is intended to be able to restrain the pace of community activities leaving the house. Almost all activities have been dismissed, and this policy is known as a lockdown. Lockdown can help prevent the spread of the coronavirus to an area so that people in that area are expected to be able 
to avoid the fast-spreading outbreak (Yunus et al., 2020).

Based on the results obtained from the article forest plot, it is known that anxiety in adults with the implementation of the policy lockdown is 1.94 times riskier than those who do not implement the policy lockdown but it is not significant in increasing anxiety in adults $(\mathrm{aOR}=1.94 ; 95 \%$ $\mathrm{CI}=0.79$ to $4.74 ; \mathrm{p}=0.150)$. This is supported by Sigdel et al. (2020) which found the conclusion that high levels of depression and anxiety and comorbidities were found in the general population during a lockdown of the COVID-19 pandemic in Nepal. A study conducted by Loyola et al. (2020) also shows an increase in stress levels which include higher levels of anxiety, depression, and poorer sleep quality during isolation in the era of the COVID-19 pandemic. Rehman et al. (2020) also show that people who do not have enough supplies to sustain the lockdown were most affected, and family affluence was found to be negatively correlated with stress, anxiety, and depression. Among different professions, students and healthcare professionals were found to experience stress, anxiety, and depression more than others. Lack of information regarding the current condition of Covid, news that is too overrated on mass media or social media are several factors that cause anxiety during the COVID-19 pandemic (Purwanto et al., 2020). In a study conducted by Fitria et al. (2020), it was stated that the anxiety level of adolescents was $54 \%$ in the high category. Sigdel (2020) result article showed that females, those living alone, health professionals, and those who spent more time accessing information about COVID19 were significantly more likely to have depression, anxiety, and depression-anxiety co-morbidity more than a man. High rates of depression and anxiety and co-morbidity were found to be prevailing among the general population during the COVID-19 pandemic lockdown in Nepal.

The limitation in this study is the existence of publication bias because researchers only use 5 indexing databases (PubMed, Google Scholar, Science Direct, Scopus, and Crossref) in searching the main study articles for meta-analysis so that other search sources are ignored. Another possibility is because the sample that fits the inclusion criteria is also small, namely 4 articles.

The conclusion from the results of this meta-analysis shows that anxiety in adults with the implementation of the policy is lockdown more at risk than those who do not implement the policy lockdown, but it is not significant in increasing anxiety in adults.

\section{AUTHOR CONTRIBUTION}

Isna Nur Rohmah, Muhammad Dudayev Caesar P, Hakim Anasulfalah contributed to data processing and analysis. Fauzia Ichlasul Sekar, Meike Arianty, Galang Aji Samudera contributed in finding and sorting articles to be used in this research. Hepti Widia Ningsih, Muhammad Fajar Husein, Masromi Hendria W, Izdihar Azzah P contributed in interpreting and writing articles.

\section{CONFLICT OF INTEREST}

There is no conflict of interest in this study.

\section{FUNDING AND SPONSORSHIP}

This study used a personal fund from the researcher.

\section{ACKNOWLEDGEMENT}

Researchers thank and give appreciation to electronic databases: PubMed, Google Scholar, Science Direct, Scopus and Crossref. 
Rohmah et al./ Meta-Analysis of the Effect of Policy Lockdown on Anxiety in Adults

\section{REFERENCE}

Alim SA, Kibria SM, Islam MJ, Uddin MZ, Nessa M, Wahab MA, Islam MM (2017). Translation of DASS 21 into Bangla and validation among medical students. Bang J Psychiatry. 28: 6770. doi: 10.3329/bjpsy.v28i2.32740.

Anjum A, Hossain S, Sikder T, Uddin ME, Rahim, DA (2019). Investigating the prevalence of and factors associated with depressive symptoms among urban and semi-urban school adolescents in Bangladesh: a pilot study. Int. Health. 00: 1-9. doi: 10.1093/inthealth/ihzo92.

Field T, Mines S, Poling S, Diego M (2020). Anxiety, Depression, and Stresors Related to a COVID-19 Lockdown. Int J Depress Anxiety. 3: 1-13. doi: 10.46527/2582-3264.124.

Fitria L, Ifdil I (2020). Kecemasan remaja pada masa pandemi covid-19. Jurnal Educatio. 6(1): 1-4. doi: 10.29210/120202592.

Handayani RT, Suminanto S, Darmayanti AT, Widiyanto A, Atmojo JT (2020). Conditions and Strategy for Anxiety in Health Workers at Pandemic Covid19. JIKJ. 3(3): 365-374. doi: 10.32584/jikj.v3i3,643.

Lovibond SH, Lovibond PF (1995). Manual for the Depression Anxiety \& Stress Scales, 2nd Ed. Psychology Foundation. Sydney.

Loyola WS, Sanchez IR, Rodriguez PP, Ganz F, Torralba R, Oliveira DV, Manas LR (2020). Impact of Social Isolation Due to COVID-19 on Health in Older People: Mental and Physical Effects and Recommendations. J Nutr Health Aging. 24(9): 938-947. doi: 10.1007/s12603-020-1469-2.

Murti B (2018). Epidemiological Research Principles and Methods. 5th Edition (Principles and Methods of Epidemio- logical Research. 5th Edition). Surakarta: Public Health Studies Program. Perhimpunan Dokter Spesialis Kedokteran Jiwa Indonesia (PDSKJI) (2020). Infografik swaperiksa cemas depresi PDSKJI. http://pdskji.org. Viewed 26 Mei 2021.

Prati G (2020). Mental health and its psychosocial predictors during national quarantine in Italy against the coronavirus disease 2019 (COVID-19). Anxiety Stress Coping. 34: 145-156. doi: $10.1080 / 10615806.2020 .18612-$ 53.

Purwanto A, Pramono R, Asbari M, Santoso PB, Wijayanti LM, Hyun CC, Putri RS (2020). Studi eksploratif dampak pandemi COVID-19 terhadap proses pembelajaran online di sekolah dasar. Edu Psy Couns J. 2(1): 1-12. https://ummaspul.e-journal.id/Edupsycouns/article/view/397.

Rehman U, Shahnawaz MG, Khan NH, Kharsiing KD, Khursheed M, Gupta K, Kashyap D, et al. (2020). Depression, anxiety and stress among Indians in times of Covid-19 lockdown. Community Mental Health J. 57: 42-48. doi: 10.1007/s10597-020-00664-X.

Roy D, Tripathy S (2020). Study of knowledge, attitude, anxiety \& perceived mental healthcare need in Indian population during COVID-19 pandemic. Asian J Psychiatr. 51: 102083. https://dx.doi.org/10.1016\%2Fj.ajp.2 020.102083 .

Sigdel A, Bista A, Bhattarai N, Pun BC, Giri G, Marqusee H, Thapa S (2020). Depression, anxiety and depressionanxiety comorbidity amid COVID-19 pandemic: An online survey conducted during lockdown in Nepal. MedRxiv. doi: 10.1101/2020.04.30.20086926. 
Rohmah et al./ Meta-Analysis of the Effect of Policy Lockdown on Anxiety in Adults

Sutejo (2018). Mental Nursing, Concepts and Practices of Mental Health Nursing: Mental and Psychosocial Disorders. Yogyakarta: New Library Press.

Thakur V, Jain A (2020). COVID 2019-suicides: A global psychological pandemic. Brain, Behavior, and Immunity. Brain Behav Immun. 88: 952-953. doi: 10.1016/j.bbi.2020.04.062.

Wang C, Pan R, Wan X (2020). Immediate psychological responses and associated factors during the initial stage of the 2019 coronavirus disease (COVID19) epidemic among the general population in China. Int $\mathrm{J}$ Environ Res Public Health. 17(5): 1729. https://dx.doi.org/10.3390\%2Fijerph17051729.
Wang C, Pan R, Wan X, Tan Y, Xu L, Ho CS, Ho RC (2020). Immediate psychological responses and associated factors during the initial stage of the 2019 coronavirus disease (COVID-19) epidemic among the general population in China. Int $\mathrm{J}$ Environ Res $\mathrm{Pu}-$ blic Health. 17: 1-25. doi: 10.3390/ijerph17051729.

Yunus NR, Rezki A (2020). Lockdown enforcement policy in anticipation of the spread of the corona virus COVID19. Syar'i Social and Cultural Journal. 7: 227-238. https://doi.org/10.15408/sjsbs.v7i3.15083. 